\title{
Synthesis of Schiff Bases Compounds from Oxamic Hydrazide: Spectroscopic Characterization, X-ray Diffraction Structure and Antioxidant Activity Study
}

\author{
Fatou Faye $^{1}$, Amadou Guèye ${ }^{1}$, Papa Samba Camara ${ }^{2}$, Aïssatou Alioune Gaye ${ }^{1}$, \\ Farba Bouyagui Tamboura ${ }^{2}$, Nathalie Gruber ${ }^{3}$, Mohamed Gaye ${ }^{1, *}$ \\ ${ }^{1}$ Department of Chemistry, University Cheikh Anta Diop, Dakar, Senegal \\ ${ }^{2}$ Department of Chemistry, University Alioune Diop, Bambey, Senegal \\ ${ }^{3}$ Institut Le Bel, University of Strasbourg, Strasbourg, France
}

Email address:

mohamedl.gaye@ucad.edu.sn (M. Gaye)

${ }^{*}$ Corresponding author

\section{To cite this article:}

Fatou Faye, Amadou Guèye, Papa Samba Camara, Aïssatou Alioune Gaye, Farba Bouyagui Tamboura, Nathalie Gruber, Mohamed Gaye. Synthesis of Schiff Bases Compounds from Oxamic Hydrazide: Spectroscopic Characterization, X-ray Diffraction Structure and Antioxidant Activity Study. American Journal of Applied Chemistry. Vol. 9, No. 1, 2021, pp. 6-12. doi: 10.11648/j.ajac.20210901.12

Received: January 2, 2021; Accepted: January 11, 2021; Published: January 22, 2021

\begin{abstract}
The compounds (E)-2-amino- $N^{\prime}-\left(1-\left(2-\right.\right.$ hydroxyphenyl)ethylidene)-2-oxoacetohydrazide (I) and $(E)-N^{\prime}-(2-$ hydroxy-3-methoxybenzylidene)-2-amino-2-oxoacetohydrazide (II) were synthetized by the 1:1 ratio condensation reaction of oxamic hydrazide and 2-hydroxyacetophenone or o-vanillin respectively. The two compounds were characterized by physico-chemical analyses, elemental analysis, FTIR, ${ }^{1} \mathrm{H}$ and ${ }^{13} \mathrm{C}$ NMR spectroscopies techniques. The structure of the compound (I) was determined by single-crystal X-ray diffraction study. The compound (I) $\left(\mathrm{C}_{10} \mathrm{H}_{11} \mathrm{~N}_{3} \mathrm{O}_{3}\right)$ crystallises in the triclinic space group $P-1$ with the following unit cell parameters: $a=7.0399$ (5) $\AA, b=8.6252$ (8) $\AA, c=9.5474$ (9) $\AA, a=$ $81.730(3)^{\circ}, b=72.738(3)^{\circ}, g=67.450(3)^{\circ}, V=510.99(8) \AA^{3}, Z=2, T=173(2) \mathrm{K}, m=0.11 \mathrm{~mm}^{-1}, D_{\text {calc }}=1.438 \mathrm{~g} / \mathrm{cm}^{3}, R_{\text {int }}$ $=0.028, R_{\text {sigma }}=0.073$. The oxamic hydrazide moiety of the molecule is slightly twisted as reflected by the torsion angles values of $177.2(2)^{\circ}[\mathrm{N} 1-\mathrm{N} 2-\mathrm{C} 9-\mathrm{C} 10],-171.3(3)^{\circ}$ [N2-C9-C10-N3], -4.6 (4) ${ }^{\circ}$ [O2-C9-N2-N1] and $8.4(4)^{\circ}[\mathrm{O} 3-\mathrm{C} 10-\mathrm{C} 9-$ N2]. The intramolecular hydrogen bond $\mathrm{O} 1$ (phenol)-H1 $\cdots \mathrm{N} 1$ (hydrazide) which close in $S$ (6) ring stabilized the conformation. The intermolecular hydrogen bonds, $\mathrm{C} 3-\mathrm{H} 3 \cdots \mathrm{O} 1^{\mathrm{i}}\left(\right.$ phenol) $(\mathrm{i}:-\mathrm{x}+1,-\mathrm{y},-\mathrm{z}+1), \mathrm{N} 3$ (amide)-H3A $\cdots \mathrm{O} 33^{\mathrm{ii}}$ (amide) (ii: $-\mathrm{x}+1$, $-\mathrm{y}+2,-\mathrm{z}$ ) and $\mathrm{N} 3$ (amide) $-\mathrm{H} 3 \mathrm{~B} \cdots \mathrm{O} 2^{\text {iiii }}$ (hydrazide) (iii: $-\mathrm{x}+1,-\mathrm{y}+1,-\mathrm{z}$ ) lead to the formation of sheets parallel to $a c$ plane. Compounds (I) and (II) showed antioxidant activities less than $10 \%$ inhibition of DPPH.
\end{abstract}

Keywords: Oxamic Hydrazide, 2-hydroxyacetophenone, O-vanillin, Antioxidant, X-ray

\section{Introduction}

Potentially ditopic Schiff bases prepared from oxamic or thioxamic hydrazide have been widely reported in the literature by chemists and in particular those interested in coordination chemistry [1-6]. Oxamic hydrazide has two different arms. The hydrazide arm condenses more easily than the amide arm with carbonyl [7-10]. The use of these ligands has made it possible to prepare coordination compounds with atypical structures [11-13]. The derivatives of oxamic hydrazide have been used for the synthesis of nucleoside $[14,15]$. Oxamic hydrazide have been used as coreactant in electroluminescence $[16,17]$. A wide variety of heterocyclic molecules with good medicinal properties are obtained starting from these oxamic precursors [18]. They are used as antibacterial agent, [19] anticonvulsant, [8] antiinflammatory [20], antituberculosis [18] and anticancer agents [4, 21]. Schiff's bases are synthesized from oxamic hydrazide and used for the preparation of complexes with transition metal and lanthanide ions [9, 22-25]. The properties of these complexes are evaluated in superoxide catalysis [2, 3] and magnetism [26]. It is in this perspective that we have studied these types of ligands and reported their 
transition metal complexes [7, 27]. Continuing our work in this field, we obtained ligands (I) and (II). In the present study, we report the spectroscopic study of the two compounds and the structure of (I) obtained by X-ray diffraction.

\section{Material and Methods}

\subsection{Materials and Physical Methods}

Oxamic hydrazide, 2'-hydroxyacetophenone, o-vanillin, cyclohexanol and 1,1-diphenyl-2-picrylhydrazyl (DPPH.) were of analytical reagent grade and were obtained from Sigma-Aldrich Company. All used solvents were of UV spectroscopic quality. The elemental analyses of $\mathrm{C}, \mathrm{H}$ and $\mathrm{N}$ were recorded on a VxRio EL Instrument. FT-IR spectra were recorded in the region of $4000-400 \mathrm{~cm}^{-1}$ using a Perkin Elmer Spectrum Two FT-IR spectrometer. The UV-Visible spectra were recorded on a Perkin Elmer Lambda UV-Vis spectrophotometer. The ${ }^{1} \mathrm{H}$ and ${ }^{13} \mathrm{C}$ NMR spectra were recorded in $\mathrm{DMSO}-\mathrm{d}_{6}$ on a Bruker $500 \mathrm{MHz}$ spectrometer at room temperature using TMS as an internal reference.

\subsection{Free Radical Scavenging Antioxidant Assay}

Antioxidant capacities of compound (I) were measured according to Akhtar et al. [28] method with modifications. The methanol solution of $3.8 \mathrm{~mL} \mathrm{DPPH} \bullet$ was added to test compounds $(200 \mu \mathrm{L})$ at different concentrations. The mixture was shaken vigorously and incubated in dark for $30 \mathrm{~min}$ at room temperature. After the incubation time, the absorbance of the solution was measured at $517 \mathrm{~nm}$ by using UV-vis spectrophotometer Perkin two. The DPPH• radical scavenger effect was calculated using the following equation:

Scavenging activity $(\%$ control $)=\frac{A_{\text {control }}-A_{\text {sample }}}{A_{\text {control }}} \times 100$

where $A_{\text {control }}$ is the absorbance of the control reaction and $A_{\text {sample }}$ is the absorbance of the test compound. The tests were carried out in triplicate. Trolox was used as positive control.

\subsection{Synthesis of (E)-2-amino-N'-(1-(2- hydroxyphenyl)ethylidene)-2-oxoacetohydrazide (I)}

Oxamic hydrazide (2.0307 g, $19.7 \mathrm{mmol})$ was suspended in $20 \mathrm{~mL}$ of cyclohexanol. 2'-hydroxyacetophenone (2.6821 g, $\quad 19.7 \mathrm{mmol}$ ) previously dissolved in $20 \mathrm{~mL}$ of cyclohexanol was added. The mixture was heated at reflux for 24 hours. On cooling, a white solid was collected by filtration, washed with $2 \times 10 \mathrm{~mL}$ of ethanol, and dried in the open air. The precipitate was recrystallized in DMF and the solution was left at room temperature. Slow evaporation of the solvent gave colorless crystals after one week. Yield: 95\%. Anal. Calc. for $\left[\mathrm{C}_{10} \mathrm{H}_{11} \mathrm{~N}_{3} \mathrm{O}_{3}\right](\%)$ : C, 54.29; H, 5.01; N, 19.00. Found: C, 54.27; H, 5.03; N, 19.03. FIT-IR (n, $\left.\mathrm{cm}^{-1}\right)$ : $3383(\mathrm{OH}), 3293(\mathrm{NH}), 3222\left(\mathrm{NH}_{2}\right), 1702(\mathrm{CONH}), 1652$ $\left(\mathrm{CONH}_{2}\right), 1606(\mathrm{C}=\mathrm{N}), 1562\left(\mathrm{C}_{\mathrm{Ar}}=\mathrm{C}_{\mathrm{Ar}}\right), 1466\left(\mathrm{C}_{\mathrm{Ar}}=\mathrm{C}_{\mathrm{Ar}}\right)$, $1411\left(\mathrm{C}_{\mathrm{Ar}}=\mathrm{C}_{\mathrm{Ar}}\right), 1250\left(\mathrm{C}-\mathrm{O}_{\text {phenol }}\right) .{ }^{1} \mathrm{H}$ RMN $\delta: 2.424(\mathrm{~S}, 3 \mathrm{H}$, $\left.\mathrm{CH}_{3}\right), 6.921-8.056\left(\mathrm{~m}, 4 \mathrm{H}, \mathrm{H}_{\mathrm{Ar}}\right), 8.396(\mathrm{Ar}-\mathrm{OH}), 9.940(\mathrm{~S}$,
1H, CONH), $11.428(\mathrm{~S}, 1 \mathrm{H}, \mathrm{HNCOH}), 12.925(\mathrm{~S}, 1 \mathrm{H}$, $\mathrm{HNCOH}) . \mathrm{RMN}^{13} \mathrm{C}\left(\mathrm{dmso}-\mathrm{d}_{6}, \mathrm{~d}(\mathrm{ppm})\right)$ : $162.232(\mathrm{C}=\mathrm{O})$, $159.198(\mathrm{HN}-\mathrm{COH}), 158.840(\mathrm{C}=\mathrm{N}), 157.840\left(\mathrm{C}_{\mathrm{Ar}}-\mathrm{OH}\right)$, $[132.344,129.416,119.607,119.231,117.812]\left(\mathrm{C}_{\mathrm{Ar}}\right), 14.677$ $\left(-\mathrm{CH}_{3}\right)$,

\subsection{Synthesis of (E)-N'-(2-hydroxy-3- methoxybenzylidene)-2-amino-2-oxoacetohydrazide (II)}

Oxamic hydrazide $(2.037 \mathrm{~g}, 19.7 \mathrm{mmol})$ was suspended in $20 \mathrm{~mL}$ of cyclohexanol. o-vanillin $(2.9973 \mathrm{~g}, 19.7 \mathrm{mmol})$ previously dissolved in $20 \mathrm{~mL}$ of cyclohexanol was added. The mixture was heated at reflux for six hours. On cooling, a solid was collected by filtration, washed with $2 \times 10 \mathrm{~mL}$ of ethanol and dried in the open air. The precipitate was recrystallized in DMF and the solution was left at room temperature. Slow evaporation of the solvent gave colorless precipitate after one week. Yield: 97\%. Anal. Calc. for $\left[\mathrm{C}_{10} \mathrm{H}_{11} \mathrm{~N}_{3} \mathrm{O}_{4}\right](\%)$ : C, 50.63; H, 4.67; N, 17.71. Found: C, 50.60; H, 4.69; N, 17.75. FT-IR (n, cm $\left.{ }^{-1}\right): 3375(\mathrm{~N}-\mathrm{H}), 3221$ $(\mathrm{O}-\mathrm{H}), 1704(\mathrm{CONH}), 1656(\mathrm{C}=\mathrm{O}), 1603(\mathrm{C}=\mathrm{N}), 1560$ $\left(\mathrm{C}_{\mathrm{Ar}}=\mathrm{C}_{\mathrm{Ar}}\right), 1464\left(\mathrm{C}_{\mathrm{Ar}}=\mathrm{C}_{\mathrm{Ar}}\right), 1409\left(\mathrm{C}_{\mathrm{Ar}}=\mathrm{C}_{\mathrm{Ar}}\right), 1252\left(\mathrm{C}-\mathrm{O}_{\text {phenol }}\right)$, $1230\left(\mathrm{C}-\mathrm{O}_{\text {ether }}\right), 1080(\mathrm{~N}-\mathrm{N}), 837\left(\mathrm{C}-\mathrm{H}_{\mathrm{Ar}}\right), 669\left(\mathrm{C}-\mathrm{H}_{\mathrm{Ar}}\right)$. RMN ${ }^{1} \mathrm{H}\left(\mathrm{dmso}^{-} \mathrm{d}_{6}, \mathrm{~d}(\mathrm{ppm})\right): 3.80\left(\mathrm{~S}, 3 \mathrm{H},-\mathrm{OCH}_{3}\right),[6.82-$ 7.10] $\left(\mathrm{m}, 3 \mathrm{H}, \mathrm{H}_{\mathrm{Ar}}\right), 7.97(\mathrm{~S}, 1 \mathrm{H}, \mathrm{CONH}), 8.30(\mathrm{~S}, 1 \mathrm{H}, \mathrm{Ar}-$ $\mathrm{OH}), 8.75(\mathrm{~S}, 1 \mathrm{H}, \mathrm{HC}=\mathrm{N}), 10.75(\mathrm{~S}, 1 \mathrm{H}, \mathrm{HNCOH}), 12.36(\mathrm{~S}$, $1 \mathrm{H}, \mathrm{HNCOH}) . \mathrm{RMN}^{13} \mathrm{C}\left(\mathrm{dmso}^{-\mathrm{d}_{6}}, \mathrm{~d}(\mathrm{ppm})\right): 161.51(\mathrm{C}=\mathrm{O})$, $156.54(\mathrm{HN}-\mathrm{COH}), 150.46(\mathrm{C}=\mathrm{N}), 147.87\left(\mathrm{C}_{\mathrm{Ar}}-\mathrm{OH}\right), 147.20$ $\left(\mathrm{C}_{\mathrm{Ar}}-\mathrm{OCH}_{3}\right),[120.65,119.03,118.72,113.96]\left(\mathrm{C}_{\mathrm{Ar}}\right), 55.76(-$ $\left.\mathrm{OCH}_{3}\right)$.<smiles>[R]C(=O)c1cccc([R])c1O</smiles><smiles>[R]/C(=N\NC(=O)C(N)=O)c1cccc([R])c1O</smiles><smiles>[R8]/C(=N\NC(=O)C(=N)O[2H])c1cccc([R2])c1O</smiles>

I : $\mathrm{R}_{1}=-\mathrm{CH}_{3}, \mathrm{R}_{2}=\mathrm{H}$ and $\mathrm{t}=24$ hours; II: $\mathrm{R}_{1}=\mathrm{H}, \mathrm{R}_{2}=-\mathrm{OCH}_{3}$ and $\mathrm{t}=6$ hours

Figure 1. Synthetic scheme of (I) and (II). 


\subsection{Crystal Structure Determination}

Crystals suitable for single-crystal X-ray diffraction, of the reported compound, was grown by slow evaporation of DMF solution of the compound. Details of the crystal structure solution and refinement are given in Table 1. Diffraction data were collected using a Bruker APEX-II CCD diffractometer with graphite monochromatized MoKa radiation $(1=0.71073 \AA)$. All data were corrected for Lorentz and polarization effects. The structure was solved and refined using the Bruker SHELXTL Software Package [29]. All the structures were refined on $F^{2}$ by a full-matrix least-squares procedure using anisotropic displacement parameters for all non-hydrogen atoms [30]. $\mathrm{H}$ atoms of the $\mathrm{NH}$ groups was located in the Fourier difference maps and refined without restraints. Other $\mathrm{H}$ atoms were geometrically optimized and refined as riding on their carriers with $U$ iso $(\mathrm{H})=$ $1.2 \mathrm{Ueq}(\mathrm{C})\left(1.5\right.$ for $\mathrm{CH}_{3}$ group). Molecular graphics were generated using ORTEP-3 [31].

\section{Result and Discussion}

\subsection{General Study}

The synthesis of Schiff bases usually takes place in simple alcohols such as methanol, ethanol or propanol. In the synthesis of Schiff bases from oxamic hydrazide, the subject of our study, the use of these solvents leads to excessively long reaction times. In fact, for the condensation of oxamic hydrazide with carbonyl compounds, it is necessary to heat to temperature high enough to shorten the reaction time. Cyclohexanol which has a high boiling point $\left(161.8^{\circ} \mathrm{C}\right)$ is suitable to prepare compounds (I) and (II) with short time reaction (Figure 1).

The results of elemental analysis agree with the expected formulas for the two compounds. The solid-state infrared spectrum of (I) reveals a broad band around $3383 \mathrm{~cm}^{-1}$ attributed to the $\mathrm{OH}$ stretching vibration and another band around $3293 \mathrm{~cm}^{-1}$ indicating the presence of NH. These two bands are present in the spectrum of compound (II) at 3375 $\mathrm{cm}^{-1}$ and $3221 \mathrm{~cm}^{-1}$ respectively $[32,33]$. The band due to the $\mathrm{C}=\mathrm{N}$ group formed after the condensation reaction between the oxamic hydrazide and the appropriate carbonyl is pointed at $1606 \mathrm{~cm}^{-1}$ for (I) and at $1603 \mathrm{~cm}^{-1}$ for (II). The stretching vibrations due to $\mathrm{C}=\mathrm{O}$ of the oxamic unit were noted at $1702 \mathrm{~cm}^{-1}$ and $1652 \mathrm{~cm}^{-1}$ for (I) and at $1704 \mathrm{~cm}^{-1}$ and $1656 \mathrm{~cm}^{-1}$ for (II) $[34,35]$. The shift of the second band towards the low frequencies is justified by the strong resonance of the oxalate group. The additional bands in the range $\left[1570-1405 \mathrm{~cm}^{-1}\right]$ are due to the aromatic groups.

The ${ }^{1} \mathrm{H}$ NMR spectra of the compounds, in DMSO- $\mathrm{d}_{6}$ solution, are recorded. Compound (I) gives two signals characteristic of iminolisation. Indeed, the single signal designating the moiety $\left[-\mathrm{C}(=\mathrm{O})-\mathrm{NH}_{2}\right]$ does not appear on the spectrum. The two signals at $11.428 \mathrm{ppm}$ and $12.925 \mathrm{ppm}$ assigned respectively to $\mathrm{HN}=\mathrm{C}-\mathrm{OH}$ and $\mathrm{HN}=\mathrm{C}-\mathrm{OH}$ are indicative of the iminolisation of the amide function of the Schiff base. The same phenomenon is observed for compound (II). The corresponding signals are pointed at $10.750 \mathrm{ppm}$ and $12.360 \mathrm{ppm}$, respectively. These observations are confirmed by ${ }^{13} \mathrm{C}$ NMR spectra in DMSO$\mathrm{d}_{6}$. Compound (I) gives a signal at $159.198 \mathrm{ppm}$ corresponding to the iminol carbon atom $\mathrm{HN}=\mathrm{C}-\mathrm{OH}$. This signal is identified at $156.540 \mathrm{ppm}$ in the spectrum of (II). The signals due to the hydrazide carbon atoms are at 162.232 ppm and $161.510 \mathrm{ppm}$ for (I) and (II) respectively. This behavior is observed in amide-iminol tautomerism [36].

Table 1. Crystal data and structure refinement for compound (I).

\begin{tabular}{|c|c|}
\hline Chemical formula & $\mathrm{C}_{10} \mathrm{H}_{11} \mathrm{~N}_{3} \mathrm{O}_{3}$ \\
\hline$M \mathrm{r}$ & 221.22 \\
\hline Crystal shape/Color & Prismatic/colorless \\
\hline Crystal system, space group & Triclinic, $P-1$ \\
\hline$T(\mathrm{~K})$ & $173(2)$ \\
\hline$a(\AA)$ & $7.0399(5)$ \\
\hline$b(\AA)$ & $8.6252(8)$ \\
\hline$c(\AA)$ & $9.5474(9)$ \\
\hline$a\left(^{\circ}\right)$ & $81.730(3)$ \\
\hline$b\left(^{\circ}\right)$ & $72.738(3)$ \\
\hline$g\left(\left(^{\circ}\right)\right.$ & $67.450(3)$ \\
\hline$V\left(\AA^{3}\right)$ & $510.99(8)$ \\
\hline$Z$ & 2 \\
\hline$D_{\text {calc }}\left(\mathrm{g} \mathrm{cm}^{-3}\right)$ & 1.438 \\
\hline $\mathrm{F}(000)$ & 232 \\
\hline Radiation type & Mo $K \alpha$ \\
\hline$\mu\left(\mathrm{mm}^{-1}\right)$ & 0.11 \\
\hline Crystal size (mm) & $0.12 \times 0.10 \times 0.10$ \\
\hline$T_{\min }, T_{\max }$ & $0.982,0.991$ \\
\hline $\mathrm{h}$ & $-7 \rightarrow 8$ \\
\hline $\mathrm{k}$ & $-11 \rightarrow 11$ \\
\hline 1 & $-12 \rightarrow 12$ \\
\hline Diffractometer & Bruker $A P E X$-II CCD \\
\hline Absorption correction & Multi-scan $S A D A B S$ \\
\hline $\begin{array}{l}\text { No. of measured, independent and } \\
\text { observed }[I>2 \sigma(I)] \text { reflections }\end{array}$ & $9791,2063,1634$ \\
\hline$R_{\text {int }}$ & 0.028 \\
\hline$R\left[F^{2}>2 \sigma\left(F^{2}\right)\right]$ & 0.073 \\
\hline$w R\left(F^{2}\right)$ & 0.227 \\
\hline$S$ & 1.09 \\
\hline No. of parameters/restraints & $147 / 0$ \\
\hline$\Delta \rho_{\max }, \Delta \rho_{\min }\left(\mathrm{e} \AA^{-3}\right)$ & $0.44,-0.29$ \\
\hline
\end{tabular}

\subsection{Crystal Structure}

The DMF solution of compound $\mathrm{C}_{10} \mathrm{H}_{11} \mathrm{~N}_{3} \mathrm{O}_{3}$ which was left for slow evaporation for two weeks gave colorless crystals suitable for $\mathrm{X}$-ray analysis. The compound crystallizes in the triclinic group $P-1$. The molecular structure with the atomic-labelling scheme is shown in figure 2. The crystal structure solution and refinement are given in Table 1. Selected bond distances and angles are listed in Table 2 . The asymmetric unit contains one organic molecule. The $-\mathrm{NH}_{2}$ of the amid group is in anti-position with respect to the hydrazide group across $\mathrm{C} 9-\mathrm{C} 10$, while the carbonyl groups are in trans-position with respect to each other, across C9-C10. The compound assumes an $E$ configuration across the $\mathrm{C} 7=\mathrm{N} 1$ bond. The ((2-hydroxyphenyl) $-2-$ ethylidene) imino moiety adopts a cis conformation with the oxygen atom $\mathrm{O} 2$ of the carbonyl through the $\mathrm{C} 9-\mathrm{N} 2$ bond. The bond lengths values of 1.221 (3) $\AA$ [C9-O2] and 1.234 (3) $\AA[\mathrm{C} 1-\mathrm{O} 3]$ are indicative of a double character as 
observed for similar compounds which crystallize in their keto forms $[37,7]$. Those distances are comparable to the values found for a derivative which has an oxalate group [38]. The bond lengths values of 1.321 (4) $\AA$ [C10-N3] and 1.340 (4) $\AA$ [C9-N2] bonds are in the normal range observed for single $\mathrm{C}-\mathrm{N}$ bonds [39]. The oxamic hydrazide fragment $\mathrm{N} 1 / \mathrm{N} 2 / \mathrm{C} 9 / \mathrm{O} 2 / \mathrm{C} 10 / \mathrm{O} 3 / \mathrm{N} 3$ is planar with a maximum deviation from the least-squares plane of -0.132 (2) $\AA$ for the N3 atom. The oxamic hydrazide moiety of the molecule is slightly twisted as reflected by the torsion angles values of $177.2(2)^{\circ}$ [N1-N2-C9-C10], -171.3 (3) ${ }^{\circ}$ [N2-C9-C10$\mathrm{N} 3],-4.6(4)^{\circ}$ [O2-C9-N2-N1] and $8.4(4)^{\circ}$ [O3-C10-C9N2].

The crystal packing of compound (I) is stabilized by intramolecular $\mathrm{O}$ (phenol) $-\mathrm{H} \cdots \mathrm{N}$ (hydrazide) and intermolecular $\mathrm{N}$ (amide) $-\mathrm{H} \cdots \mathrm{O}$ (amide), $\mathrm{N}$ (amide)$\mathrm{H} \cdots \mathrm{O}$ (hydrazide) and $\mathrm{C}-\mathrm{H} \cdots \mathrm{O}$ (phenol) hydrogen bonds. The intramolecular hydrogen bond O1(phenol)H1 $\cdots$ N1(hydrazide) which close in $S$ (6) ring stabilized the conformation. Intermolecular hydrogen bonds, C3$\mathrm{H} 3 \cdots \mathrm{O} 1^{\mathrm{i}}($ phenol) $\quad(\mathrm{i}: \quad-\mathrm{x}+1, \quad-\mathrm{y}, \quad-\mathrm{z}+1) \quad \mathrm{N} 3$ (amide)
$\mathrm{H} 3 \mathrm{~A} \cdots \mathrm{O} 33^{\mathrm{ii}}$ (amide) (ii: $\left.-\mathrm{x}+1,-\mathrm{y}+2,-\mathrm{z}\right)$ and N3(amide)$\mathrm{H} 3 \mathrm{~B} \cdots \mathrm{O} 2$ iii (hydrazide) (iii: $-\mathrm{x}+1,-\mathrm{y}+1,-\mathrm{z}$ ) lead to the formation of sheets parallel to $a c$ plane (Figure 3, Table 3 ).

Table 2. Selected geometric parameters $\left(\AA,{ }^{\circ}\right)$.

\begin{tabular}{llll}
\hline $\mathrm{C} 2-\mathrm{O} 1$ & $1.362(4)$ & $\mathrm{C} 9-\mathrm{O} 2$ & $1.221(3)$ \\
$\mathrm{C} 7-\mathrm{N} 1$ & $1.286(4)$ & $\mathrm{C} 10-\mathrm{O} 3$ & $1.234(3)$ \\
$\mathrm{N} 1-\mathrm{N} 2$ & $1.371(3)$ & $\mathrm{C} 10-\mathrm{N} 3$ & $1.321(4)$ \\
$\mathrm{C} 9-\mathrm{N} 2$ & $1.340(4)$ & & \\
$\mathrm{N} 1-\mathrm{C} 7-\mathrm{C} 1$ & $114.7(2)$ & $\mathrm{O} 2-\mathrm{C} 9-\mathrm{C} 10$ & $122.9(2)$ \\
$\mathrm{N} 1-\mathrm{C} 7-\mathrm{C} 8$ & $123.5(3)$ & $\mathrm{N} 2-\mathrm{C} 9-\mathrm{C} 10$ & $111.5(2)$ \\
$\mathrm{C} 1-\mathrm{C} 7-\mathrm{C} 8$ & $121.8(3)$ & $\mathrm{O} 3-\mathrm{C} 10-\mathrm{N} 3$ & $126.3(3)$ \\
$\mathrm{O} 2-\mathrm{C} 9-\mathrm{N} 2$ & $125.6(2)$ & $\mathrm{O} 3-\mathrm{C} 10-\mathrm{C} 9$ & $119.6(2)$ \\
\hline
\end{tabular}

Table 3. Hydrogen-bond geometry $\left(\AA,^{\circ}\right)$.

\begin{tabular}{lllll}
\hline $\boldsymbol{D}-\mathbf{H} \cdots \boldsymbol{A}$ & $\boldsymbol{D}-\mathbf{H}$ & $\mathbf{H} \cdots \boldsymbol{A}$ & $\boldsymbol{D} \cdots \boldsymbol{A}$ & $\boldsymbol{D}-\mathbf{H} \cdots \boldsymbol{A}$ \\
\hline $\mathrm{C} 3-\mathrm{H} 3 \cdots \mathrm{O} 1^{\mathrm{i}}$ & 0.95 & 2.51 & $3.395(4)$ & 154.9 \\
$\mathrm{O} 1-\mathrm{H} 1 \cdots \mathrm{N} 1$ & 0.84 & 1.79 & $2.521(3)$ & 144.3 \\
N3-H3A $\cdots$ O $3{ }^{\text {ii }}$ & 0.88 & 2.11 & $2.946(3)$ & 158.6 \\
N3-H3B $\cdots 2^{\text {iii }}$ & 0.88 & 2.23 & $3.022(3)$ & 150.1 \\
\hline
\end{tabular}

Symmetry codes: (i) $-\mathrm{x}+1,-\mathrm{y},-\mathrm{z}+1$; (ii) $-\mathrm{x}+1,-\mathrm{y}+2,-\mathrm{z}$; (iii) $-\mathrm{x}+1,-\mathrm{y}+1$, $-\mathrm{z}$.

Table 4. Antioxidant activity of (I) and (II) at different concentration of DPPH.

\begin{tabular}{llllll}
\hline \multirow{2}{*}{ Concentration $(\boldsymbol{\mu M})$} & {$[\mathbf{D P P H}=\mathbf{0 . 1 0 1 4} \mathbf{~ m M}$} & & \multicolumn{3}{c}{$[\mathbf{D P P H}]=\mathbf{0 . 0 5 0 7} \mathbf{~ m M ~}$} \\
\cline { 2 - 6 } & Trolox & (I) & (II) & Trolox & (I) \\
\hline 50 & $3.92 \pm 0.04$ & $1.84 \pm 0.08$ & $1.58 \pm 0.4$ & $3.35 \pm 0.05$ & $4.84 \pm 0.11$ \\
100 & $8.42 \pm 0.06$ & $1.32 \pm 0.11$ & $2.63 \pm 0.02$ & $11.60 \pm 0.012$ & $4.32 \pm 0.23$ \\
200 & $18.34 \pm 0.13$ & $3.42 \pm 0.13$ & $3.95 \pm 0.05$ & $23.45 \pm 00.11$ & $6.42 \pm 0.15$ \\
300 & $27.22 \pm 0.22$ & $5.53 \pm 0.08$ & $6.05 \pm 0.05$ & $51.03 \pm 0.13$ & $8.53 \pm 0.18$ \\
400 & $42.10 \pm 0.18$ & $6.32 \pm 0.09$ & $5.26 \pm 0.09$ & $81.70 \pm 0.09$ & $9.32 \pm 0.12$ \\
500 & $51.67 \pm 0.13$ & $6.32 \pm 0.05$ & $4.74 \pm 0.06$ & $93.30 \pm 0.08$ & $9.05 \pm 0.09$ \\
\hline
\end{tabular}

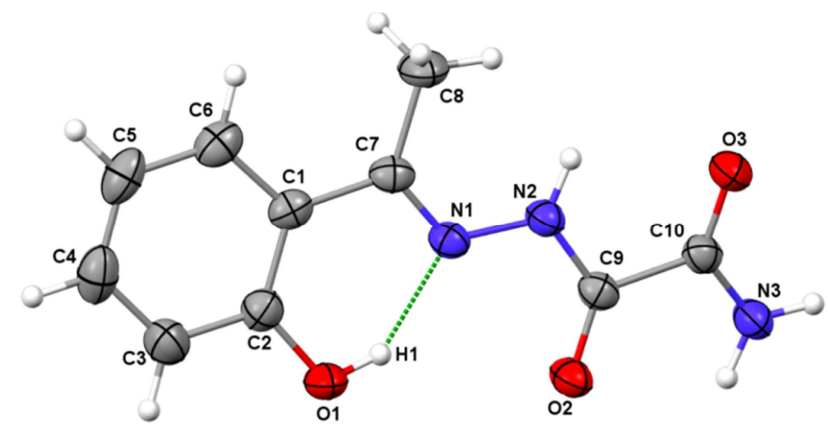

Figure 2. The crystal structure of the compound (I). Displacement ellipsoids are drawn at the 30\% probability level and $H$ atoms are shown as small sphere.

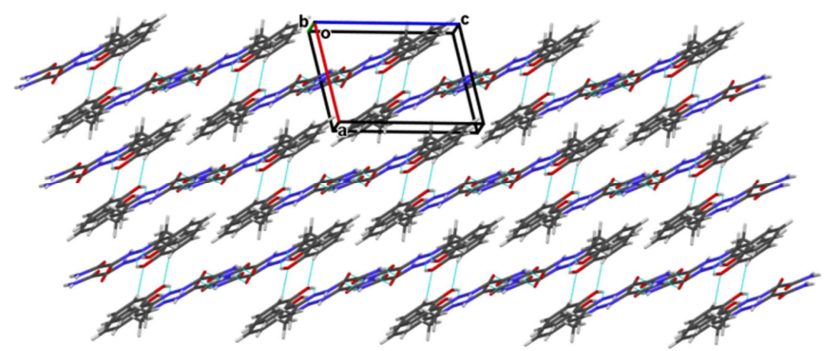

Figure 3. Chain formed by hydrogen bonds in the title compound (I) along ac plane.

\subsection{Antioxidant Activity}

$\mathrm{DPPH}^{-}$is a stable free radical which becomes a stable molecule when it accepts an electron or hydrogen radical. $\mathrm{DPPH}^{*}$ radical scavenging is a method widely used to evaluate the antioxidant activity of compounds [40, 41]. The capacity of scavenging $\mathrm{DPPH}^{\circ}$ radical of the two compounds (I) and (II) have been screened (Table 4). The Figure 4 shows the plots of $\mathrm{DPPH}^{*}$ free radical scavenging activity (\%) for the compounds (I) and (II). For compound (I), the scavenging activity increases with increasing the concentration in the range tested $(50-500 \mathrm{mmol} / \mathrm{L})$ for the two $\mathrm{DDPH}^{\circ}$ initial concentrations. The scavenging activity of (I) varies, for the highest $\mathrm{DPPH}^{\circ}(0.1014 \mathrm{mM})$ concentration, in the range $1.84 \pm 0.08-6.32 \pm 0.05 \%$ and between $4.84 \pm 0.11$ and $9.32 \pm 0.09 \%$ for the lowest $\mathrm{DPPH}^{\circ}$ concentration $(0.0507$ $\mathrm{mM}$ ). This activity is due to the $\mathrm{NH}$ or $\mathrm{OH}$ groups which can react with $\mathrm{DPPH}^{*}$ radical by the typical $\mathrm{H}$-abstraction reaction to form a stable radical. Radical scavenging activity of compound (II) $[(1.58 \pm 0.15-4.74 \pm 0.11 \%$ for the highest $\mathrm{DPPH}^{\circ}$ concentration), $(1.58 \pm 0.15-4.74 \pm 0.11 \%$ for the lowest $\mathrm{DPPH}^{\circ}$ concentration)] is slightly lower than that observed for compound (I) in the concentration range screened (Figure 4). Comparatively to the scavenging activity of Trolox $\left(3.92 \pm 0.04-51.67 \pm 0.13 \%\right.$ for the highest $\mathrm{DPPH}^{\circ}$ concentration), $(3.35 \pm 0.05-93.30 \pm 0.08 \%$ for the lowest 
DPPH concentration)]), the values observed for compounds (I) and (II) are lower than those of Trolox in concentration

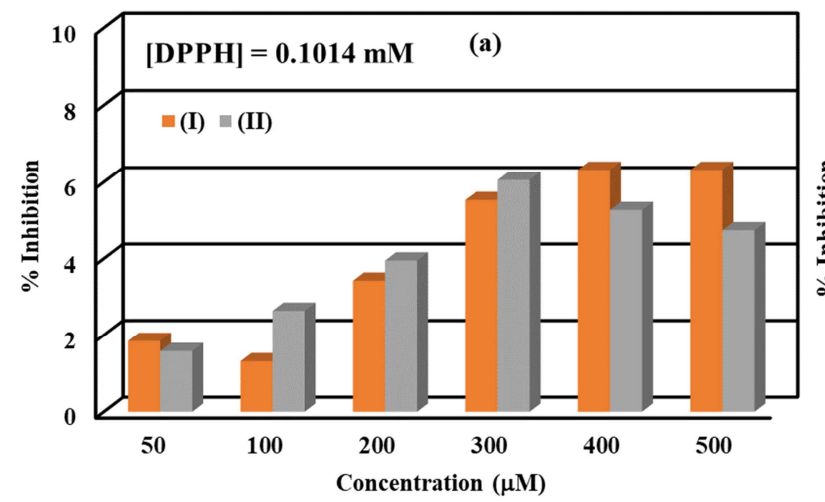

Figure 4. Antioxidant activity of (I) and (II):

\section{Conclusion}

The compounds (E)-2-amino- $N^{\prime}-(1-(2-$ hydroxyphenyl)ethylidene)-2-oxoacetohydrazide (I) and $(E)$ $N$-(2-hydroxy-3-methoxybenzylidene)-2-amino-2-

oxoacetohydrazide (II) were successfully synthesized condensation reaction of oxamic hydrazide and 2hydroxyacetophenone or o-vanillin respectively. The structures of the compounds were confirmed by elemental analysis and spectroscopic techniques (FT-IR, ${ }^{1} \mathrm{H}$ and ${ }^{13} \mathrm{C}$ NMR). The molecular structure of the (I) was also determined using X-ray crystallography technique. Compounds (I) and (II) showed low antioxidant activity of about $10 \%$ in the screened concentration range [50-500 ppm].

\section{Supplementary Materials}

CCDC-2049222 contains the supplementary crystallographic data for this paper. These data can be obtained free of charge via https://www.ccdc.cam.ac.uk/structures/, or by e-mailing data_request@ccdc.cam.ac.uk, or by contacting The Cambridge Crystallographic Data Centre, 12 Union Road, Cambridge CB2 1EZ, UK; fax: +44 (0) 1223-336033.

\section{References}

[1] Čobeljić, B., Pevec, A., Turel, I., Spasojević, V., Milčić, M., Mitić, D., Sladić, D. and Anđelković, K. (2014). Analysis of the structures of the $\mathrm{Cu}$ (I) and $\mathrm{Cu}$ (II) complexes with 3acetylpyridine and thiocyanate. Polyhedron, 69: 77-83.

[2] Gutman, C. T. and Brunold, T. C. (2012). Spectroscopic and computational studies of a small-molecule functional mimic of iron superoxide dismutase, iron 2,6-diacetylpyridinebis (semioxamazide). Inorganic Chemistry, 51 (23): 1272912737.

[3] Gutman, C. T., Guzei, I. A. and Brunold, T. C. (2013). Structural, spectroscopic, and computational characterization of the azide adduct of $\mathrm{Fe}^{\mathrm{III}}$ (2,6-diacetylpyridinebis (semioxamazide)), a functional analogue of iron superoxide range investigated $(50-500 \mathrm{mM})$. The scavenging activity of compounds (I) and (II) are low and do not exceed 10\%.

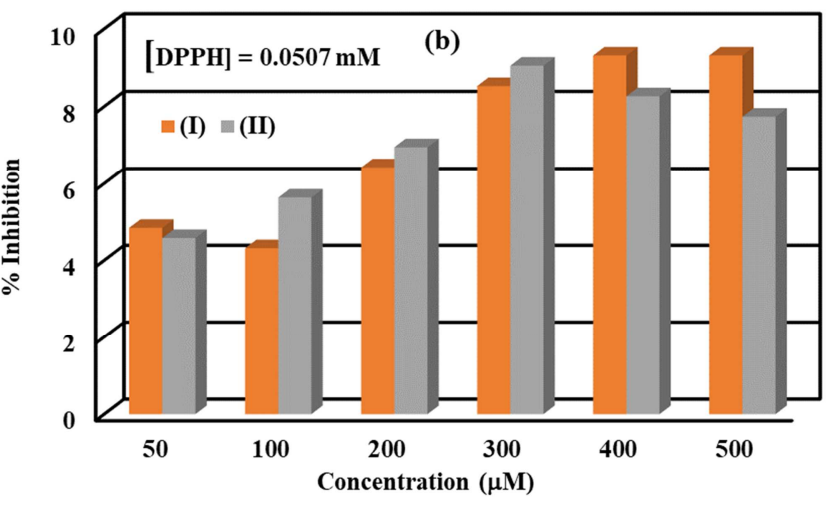

] $=0.1014 \mathrm{mM}$ and $(b)[D P P H]=0.0507 \mathrm{mM}$.

dismutase. Inorganic Chemistry, 52 (15): 8909-8918.

[4] Jarestan, M., Khalatbari, K., pouraei, A., Sadat Shandiz, S. A., Beigi, S., Hedayati, M., Majlesi, A., Akbari, F. and Salehzadeh, A. (2020). Preparation, characterization, and anticancer efficacy of novel cobalt oxide nanoparticles conjugated with thiosemicarbazide. 3 Biotech, 10 (5): 230.

[5] Haba, P., Sow, M. M., Sarr, M., Thiam, I. E., Diaw, M. and Gaye, M. L. (2020). Syntheses, characterization and X-ray crystal structure of polymeric heteronuclear oxo-bridged $\mathrm{Fe} / \mathrm{Na}$ assembled with salen-type Schiff base and dicyanamide. Sciences Journal of Chemistry, 8 (2): 20-27.

[6] Li, S., Khan, M. H., Wang, X., Cai, M., Zhang, J., Jiang, M., Zhang, Z., Wen, X., Liang, H. and Yang, F. (2020). Synthesis of a series of novel In (III) 2,6-diacetylpyridine bis (thiosemicarbazide) complexes: structure, anticancer function and mechanism. Dalton Trans, 49 (47): 17207-17220.

[7] Kane, C. H., Thiam, E. I., Tamboura, F. B., Gaye, M. and Retailleau, P. (2012). Bis $\{2-$ Amino-2-oxo- $N-[(1 E)-1-$ (pyridin-2-yl-kN)ethylidene]acetohydrazidato- $\mathrm{k}^{2} N^{\prime}$,

$O^{1}$ \}nickel (II). Acta Crystallographica E, 68 (5), m553.

[8] Dimmock, J. R., Vashishtha, S. C. and Stables, J. P. (2000). Anticonvulsant properties of various acetylhydrazones, oxamoylhydrazones and semicarbazones derived from aromatic and unsaturated carbonyl compounds. Eurpean Journal of Medicinal Chemistry, 35 (2): 241-248.

[9] Sumar, M., Ivanovic-Burmazovic, I., Hodzic, I. and Andjelkovic, K. (2002). Pentagonal-bipyramidal Mn (II) and $\mathrm{Zn}$ (II) complexes with $2^{\prime}, 2^{\prime \prime \prime}-$ (2,6-pyridindiyldiethylidene)dioxamohydrazide. Synthesis and Reactivity in Inorganic and Metal-Organic Chemistry, 32 (4): 721-737.

[10] Quaeyhaegens, F., Desseyn, H. O., Bracke, B. and Lenstra, A. T. H. (1990). Vibrational analysis of different isomers of oxalyldihydrazide and the crystal structure of the "trans-trans" form. Journal of Molecular Structure, 238: 139-157.

[11] Quaeyhaegens, F., Hofmans, H. and Desseyn, H. O. (1987). The vibrational spectra of the Ni (II) and Cu (II) complexes with oxamic hydrazide. Spectrochimica Acta Part A, 43 (4): 531-537.

[12] Quaeyhaegens, F., Perlepes, S. P. and Desseyn, H. O. (1987). The vibrational spectra of Pd (II) complexes with planar monosubstituted oxamides. Spectrochimica Acta Part A, 43 (7): 917-923. 
[13] Perlepes, S. P., Quaeyhaegens, F. J. and Desseyn, H. O. (1990). Synthesis, spectroscopy and thermal properties of the nickel (II), palladium (II) and copper (II) complexes of oxalyldihydrazide. Transition Metal Chemistry, 15 (2): 132140.

[14] Huynh-Dinh, T., Igolen, J., Bisagni, E., Marquet, J. P. and Civier, A. (1977). Synthesis of C-nucleosides. Part 14. 5 (3)glycosyl-1,2,4-triazole-3 (5) carboxamides as analogues of ribavirin. Journal of Chemical Society Perkin Trans 1, 7, 761764.

[15] Chudinov, M. V., Konstantinova, I. D., Ryzhova, O. I., Esipov, R. S., Yurkevich, A. M., Shvets, V. I. and Miroshnikov, A. I. (2005). A new effective method for the synthesis of $1,2,4$ triazole-3-carboxamide and ribavirin derivatives. Pharmaceutical Chemistry Journal, 39 (4): 212-215.

[16] Lan, Y., Yuan, F., Tadesse Haile Fereja, T. H., Lou, B., Han, S., Li, J. and Xu, G. (2019). Electrochemiluminescence of 3,4,9,10-perylenetetracarboxylic acid/oxamic hydrazide and its application in the detection of tannic acid. Analyst, 144 (15): 4449-4720.

[17] Chen, M., Ning, Z., Chen, K., Zhang, Y. and Shen, Y. (2020). Recent advances of electrochemiluminescent system in bioassay. Journal of Analysis and Testing, 4 (2): 57-75.

[18] Narang, R., Narasimhan, B. and Sharma, S. (2012). A review on biological activities and chemical synthesis of hydrazide derivatives. Current Medicinal Chemistry, 19 (4): 569-612.

[19] Hakobyan, S., Boily, J.-F. and Ramstedt, M. (2014). Proton and gallium (III) binding properties of a biologically active salicylidene acylhydrazide. Journal of Inorganic Biochemistry, 138: 9-15.

[20] Altowyan, M. S., Ali, M., Soliman, S. M., Al-Majid, A. M., Islam, M. S., Yousuf, S., Choudhary, M. I., Ghabbour, H. A. and Barakat, A. (2020). Synthesis, computational studies and biological activity of oxamohydrazide derivatives bearing isatin and ferrocene scaffolds. Journal of Molecular Structure, 1202: 127372.

[21] Mohan, M., Agarawal, A. and Jha, N. K. (1988). Synthesis, characterization, and antitumor properties of some metal complexes of 2,6-diacetylpyridine bis (N-4-azacyclic thiosemicarbazones). Journal of Inorganic Biochemistry, 34 (1): 41-54.

[22] Ivanovic-Burmazovic, I., Hamza, M. S. A. and van Eldik, R. (2002). A detailed mechanistic study of the substitution behavior of an unusual seven-coordinate iron (III) complex in aqueous solution. Inorganic Chemistry, 41 (20): 5150-5161.

[23] El-Toukhy, A. (1991). Stoichiometry, Products and kinetics of oxidation of neutral 2,6-diacetylpyridine-bis (N-4-azacyclic thiosemicarbazone) Cobalt (II) complexes by dioxygen in aprotic solvents. Inorganica Chimica Acta, 180 (1): 85-91.

[24] de Sousa, G. F., Deflon, V. M., Gambardella, M. T. do P., Francisco, R. H. P., Ardisson, J. D. and Niquet, E. (2006). XRay crystallographic and mössbauer spectroscopic applications in dependence of partial quadrupole splitting, [R], on the $\mathrm{C}-\mathrm{Sn}-\mathrm{C}$ angle in seven-coordinated diorganotin (IV) complexes. Inorganic Chemistry, 45 (11): 4518-4525.

[25] Aljahdali, M., El-Sherif, A. A., Shoukry, M. M., Hosny, W. M. and Abd-Elmoghny, M. G. (2013). Complex formation equilibria of unusual seven coordinate Fe (III) complexes with DNA constituents. Journal of Solution Chemistry, 42 (8):
$1663-1679$.

[26] Liu, G.-F., Filipović, M., Heinemann, F. W. and IvanovićBurmazović, I. (2007). Seven-coordinate iron and manganese complexes with acyclic and rigid pentadentate chelates and their superoxide dismutase activity. Inorganic Chemistry, 46 (21): $8825-8835$.

[27] Gaye, P. A., Sy, A., Sarr, A. D., Gaye M. and Besnard, C. (2011). 1- (Thiophen-2-yl)ethanone thiosemicarbazone. Acta Crystallographica E, 67 (5): o1168.

[28] Akhtar, P., Yaakob, Z., Ahmed, Y., Shahinuzzaman, M. and Hyder, M. K. M. (2018). Total phenolic contents and free radical scavenging activity of different parts of Jatropha species. Asian Journal of Chemistry, 30 (2): 365-370.

[29] Sheldrick, G. M. (2015). It SHELXT-Integrated space-group and crystal-structure determination. Acta Crystallographica A, $71(1): 3-8$.

[30] Sheldrick, G. M. (2015). Crystal structure refinement with It SHELXL. Acta Crystallographica C, 71 (1): 3-8.

[31] Farrugia, L. J. (2012). It WinGX and It ORTEP for Windows: An Update. Journal of Applied Crystallographica, 45 (4): 849-854.

[32] Singh, A. K., Pandey, O. P. and Sengupta, S. K. (2013). Synthesis, spectral and antimicrobial activity of $\mathrm{Zn}$ (II) complexes with Schiff bases derived from 2-hydrazino-5[substituted phenyl]-1,3,4-thiadiazole and benzaldehyde /2hydroxyacetophenone / indoline-2,3-dione. Spectrochimica Acta Part A, 113: 393-399.

[33] Saghatforoush, L. A., Hosseinpour, S., Bezpalko, M. W. and Kassel, W. S. (2019). X-Ray crystal structural and spectral studies of copper (II) and nickel (II) complexes of functionalized bis (thiosemicarbazone) ligands and investigation of their electrochemical behavior. Inorganica Chimica Acta, 484: 527-534.

[34] Tripathi, G. N. R. and Katon, J. E. (1979). Vibrational spectra and structure of crystalline oxalyl hydrazide and semioxamazide. Journal of Molecular Structure, 54: 19-29.

[35] Mashevskaya, M. S., Kolla, V. É., Nazmetdinov, F. Ya., Plaksina, A. N. and Semenova, Z. N. (1991). Synthesis of oxalic acid arylidenedihydrazides and their biological activity. Pharmaceutical Chemistry Journal, 25 (2), 83-85.

[36] Chandra, S. and Sharma, A. K. (2009). Nickel (II) and Copper (II) complexes with Schiff base ligand 2,6-diacetylpyridine bis (carbohydrazone): synthesis and IR, Mass, ${ }^{H}$ NMR, electronic and EPR spectral studies. Spectrochimica Acta Part A, 72 (4): 851-857.

[37] Karimian, R., Hosseini-Monfared, H., Bikas, R., Arslan, N. B., Kazak, C. and Koroglu, A. (2012). (E,E)-N-4-[(2benzoylhydrazin-1-ylidene)methyl]benzylidenebenzo hydrazide. Acta Crystallographica E, 68 (5): o1433.

[38] Tai, X.-S., Yin, J. and Kong, F.-Y. (2007). Crystal structure of 2-carboxybenzaldehyde furan-2-carbohydrazide methanol hemisolvate, $\mathrm{C}_{13} \mathrm{H}_{10} \mathrm{~N}_{2} \mathrm{O}_{4} \cdot 0.5 \mathrm{CH}_{3} \mathrm{OH}$. Zeitschrift für Kristallographie-New Crystal Structures, 222 (4): 401-402.

[39] Monfared, H. H., Bikas, R. and Mayer, P. (2010). (E)-3Hydroxy- $N^{\prime}-$ (2-hydroxybenzylidene)-2-naphthohydrazide. Acta Crystallographica E, 66 (1), o236-0237. 
[40] Taha, Z. A., Ajlouni, A. M., Momani, W. A. and Al-Ghzawi, A. A. (2011). Syntheses, characterization, biological activities and photophysical properties of lanthanides complexes with a tetradentate Schiff base ligand. Spectrochimica Acta Part A, 81 (1): 570-577.
[41] Foti, M. C., Daquino, C. and Geraci, C. (2004). Electrontransfer reaction of cinnamic acids and their methyl esters with the $\mathrm{DPPH} \bullet$ radical in alcoholic solutions. Journal of Organic Chemistry, 69 (7): 2309-2314. 